\title{
Characterization of genetic diversity on tropical Trichoderma germplasm by sequencing of rRNA internal transcribed spacers
}

\author{
Yara Barros Feitosa ${ }^{1,2}$, Valter Cruz-Magalhães ${ }^{2,3^{*}} \mathbb{0}$, Ronaldo Costa Argolo-Filho ${ }^{2}$, Jorge Teodoro de Souza ${ }^{3}$
} and Leandro Lopes Loguercio ${ }^{2}$

\begin{abstract}
Objective: Trichoderma species are found in soil and in association with plants. They can act directly or indirectly in the biological control of plant diseases and in the promotion of plant growth, being among the most used fungi in the formulation of bioproducts applied to agricultural systems. The main objective of this study was to characterize at a first-tier level a collection of 67 Trichoderma isolates from various tropical sources, based solely on sequencing of the internal transcribed spacer (ITS) region of the rRNA genes. Our goal was to provide a preliminary idea of the baseline diversity in this collection, to combine this information later with an array of other isolate-specific physiological data. This study provides a required knowledge at molecular level for assessment of this germplasm potential as a source of biotechnological products for beneficial effects in plants.

Results: Sequencing of the ITS region showed that the 67 Trichoderma isolates belonged in 11 species: T. asperellum, T. atroviride, T. brevicompactum, T. harzianum, T. koningiopsis, T. Iongibrachiatum, T. pleuroticola, T. reesei, T. spirale, T. stromaticum and T. virens. A total of $40.3 \%$ of the isolates were very closely related to each other and similar to $T$. harzianum. The baseline genetic diversity found indicates that the collection has different genotypes, which can be exploited further as a source of bioproducts, aiming at providing beneficial effects to plants of interest to cope with biotic and abiotic stresses.
\end{abstract}

Keywords: Biological control, Polymerase chain reaction, Internal transcribed spacer, BlastN, Phylogeny, Biotechnological development

\section{Introduction}

Filamentous fungi of the genus Trichoderma (Ascomycota) are among the microorganisms most used in biological control of plant diseases [1], displaying mechanisms of action that include direct and indirect antagonism against plant pathogens [2]. Trichoderma can establish endophytic associations with plants, systemically induce resistance against phytopathogens, increase nutrient uptake, and consequently promote plant growth [3]. They

\footnotetext{
*Correspondence: valter.magalhaes@ufla.br

${ }^{3}$ Department of Phytopathology (DFP), Federal University of Lavras (UFLA), Lavras, Minas Gerais 37200-000, Brazil

Full list of author information is available at the end of the article
}

are also known for their abilities to grow under diverse environmental conditions and to parasitize other fungi [4]. Due to these features, Trichoderma can colonize an array of niches and compete with other microorganisms for space, nutrients and light, which explains its success as a biological control agent [5]. All these characteristics, associated with a recognized efficacy in the generation of dispersive propagules (conidia), make Trichoderma spp. ideal for the development of bioproducts for beneficial effects on plants [6]. Several abiotic factors (light, temperature, humidity, $\mathrm{pH}$, carbon and nitrogen sources, oxygen) can interact with genetic components (inherent genetic variability of different Trichoderma isolates), 
producing unique growth and sporulation responses, which tend to contribute to the biocontrol efficacy in a strain-specific manner [7-9]. The internal transcribed spacer (ITS) region of rRNA genes is considered the primary barcode sequence for evolutionary/phylogenetic studies on fungi, due to its relevant features such as (i) ease of amplification in a very reproducible manner (ii) a widespread use among a variety of fungal systems (iii) a tendency of displaying a large barcode gap, (iv) the possibility of alignment across all the kingdom, and (v) an appropriate length for amplification, sequencing and phylogenetic information supply $[10,11]$. In this study, direct amplicon sequencing of the ITS region of rDNA was used to preliminarily characterize a tropical collection of 67 Trichoderma isolates from the Atlantic and Amazon rainforests, and 'caatinga' (semi-arid) biomes of Brazil. This collection has been evaluated concerning isolate-specific phenotypes related to growth and sporulation levels responsive to biotic and abiotic factors [12]. Based on the molecular characterization of Trichoderma isolates described in the present work, further studies on this germplasm will address its potential as a source of new bioproducts to be used in biological control of plant diseases and other beneficial effects.

\section{Main text \\ Methods \\ Trichoderma isolates and growth conditions}

The Trichoderma collection studied consisted of 67 isolates obtained from different natural environments (biomes) in different provinces of Brazil, including Bahia (47), Amazonas (9), Rondônia (10) and Minas Gerais (1) (Additional file 1: Table S1). The isolates were cultured in Petri dishes containing PDA medium $\left(\right.$ Difco $^{\mathrm{TM}}$ ) and incubated at $25{ }^{\circ} \mathrm{C}$ under constant light. After 5 days, the conidia were collected and stored in sterile glycerol (50\%) at $-80{ }^{\circ} \mathrm{C}$.

\section{Genomic DNA extraction and amplification}

For a first-tier molecular identification of Trichoderma species and an assessment of the baseline diversity of isolates within the collection, the ITS region of the rDNA was sequenced. Each isolate was grown in $30 \mathrm{~mL}$ of PD medium (inside $50-\mathrm{mL}$ Falcon tubes) at $25^{\circ} \mathrm{C}$ under constant light for 4 days in a growth chamber. For genomic DNA extraction, an initial step of physical mycelium break was employed through addition of $7-10 \mathrm{~mL}$ of sterile glass beads in each tube and vortexing for $2 \mathrm{~min}$. Afterwards, $13 \mathrm{~mL}$ of each grinded mycelium suspension was transferred to clean $50-\mathrm{mL}$ tubes and centrifuged for $5 \mathrm{~min}$ at 13,400 rpm. A wet weight of $200 \mathrm{mg}$ for each pellet was then used for total DNA extraction with the DNeasy ${ }^{\circledR}$ Plant Mini Kit $\left(\right.$ Qiagen $^{\mathrm{TM}}$ ) following the manufacturer's protocol. The ITS region was amplified by PCR using the ITS-1 [13] and ITS-4 [14] universal primers. The PCR mixture $(40 \mu \mathrm{L})$ contained $0.5 \mu \mathrm{L}$ of $2{\mathrm{U} \mu \mathrm{L}^{-1} \text { Taq DNA polymerase (Invitrogen }}^{\mathrm{TM}}$ ), $1.2 \mu \mathrm{L}$ of $1.5 \mathrm{mM} \mathrm{MgCl}, 1.67 \mu \mathrm{L}$ of each forward and reverse primers (both as $20-\mu \mathrm{M}$ solutions), $1 \mu \mathrm{L}$ of $1 \mathrm{mM}$ dNTPs (250 $\mu \mathrm{M}$ each), $4 \mu \mathrm{L}$ of $10 \times$ buffer, $3.4 \mu \mathrm{L}$ of DNA template $(\sim 10-30 \mathrm{ng})$ and $26.56 \mu \mathrm{L}$ of distilled water. Amplifications were performed in 0.2-mL PCR tubes using an Applied Biosystems Veriti Thermal Cycler. The conditions for PCR amplification were $95{ }^{\circ} \mathrm{C}$ for $5 \mathrm{~min}$, followed by 35 cycles of $95{ }^{\circ} \mathrm{C}$ for $30 \mathrm{~s}, 55^{\circ} \mathrm{C}$ for $30 \mathrm{~s}$ and $72{ }^{\circ} \mathrm{C}$ for $30 \mathrm{~s}$, and a final extension at $72{ }^{\circ} \mathrm{C}$ for $10 \mathrm{~min}$. PCR products were visualized on $1.5 \%$ agarose gel and the amplified DNA was purified from the gel using the PureLink $^{\circledR}$ Quick Gel Extraction Kit (Invitrogen ${ }^{\mathrm{TM}}$ ) following the manufacturer's instructions.

\section{Internal transcribed spacer (ITS) sequencing}

Direct sequencing of the purified amplicons was performed by the Sanger method using the ABI-PRISM ${ }^{\circledR}$ 3100 Genetic Analyzer system. Sequencing reactions in final volumes of $10 \mu \mathrm{L}$ contained $3 \mu \mathrm{L}$ of BigDye Terminator v3.1 Cycle Sequencing RR-100, $5 \mathrm{ng} \mu \mathrm{L}^{-1}$ of DNA template, and $0.25 \mathrm{pmol}_{\mu} \mathrm{L}^{-1}$ of each ITS1 or ITS4 primers. Sequencing amplifications were performed in a GeneAmp PCR System 9700 thermocycler as follows: $3 \mathrm{~min}$ at $96^{\circ} \mathrm{C}$, plus 25 cycles of $10 \mathrm{~s}$ at $96^{\circ} \mathrm{C}, 5 \mathrm{~s}$ at $55^{\circ} \mathrm{C}$ and $4 \mathrm{~min}$ at $60^{\circ} \mathrm{C}$. The reaction products were precipitated with $40 \mu \mathrm{L} 75 \%$ isopropanol $(3: 1, \mathrm{v} / \mathrm{v})$ for $20-30 \mathrm{~min}$ at room temperature, centrifuged at $13,000 \mathrm{rpm}$ for 15 min at $4{ }^{\circ} \mathrm{C}$, washed with $200 \mu \mathrm{L} 60 \%$ ethanol (quick vortexing), and centrifuged at 13,000 rpm for $5 \mathrm{~min}$ at $4{ }^{\circ} \mathrm{C}$. The pellets were air-dried, resuspended in $10 \mu \mathrm{L}$ of $\mathrm{Hi}$-Di formamide, denatured at $95{ }^{\circ} \mathrm{C}$ for $5 \mathrm{~min}$, cooled on ice for $5 \mathrm{~min}$ and electro-injected in the automatic sequencer. The sequencing data were collected using the Data Collection v 1.0.1 program. At least two sequencing reactions were performed for each amplicon/isolate.

\section{Phylogenetic and diversity analyses}

Sequences from the ITS region of the isolates were compared to those in GenBank (NCBI) through the BlastN program [15]. From these results, reference sequences for the corresponding Trichoderma species (Additional file 2: Table S2) were used to construct multiple sequence alignments (MSA). For the phylogenetic approach, the GUIDANCE2 server [16] with the MAFFT alignment algorithm [17] was used to ensure that only positions with high probabilities of being correctly aligned were used. Phylogenetic analysis was performed with the MEGA7 program [18] using the Maximum Likelihood (ML) method. The analysis involved a total of $80 \mathrm{DNA}$ 
sequences, 67 for our study and 13 type species from the database. The tree was edited using the FigTree program [19].

\section{Results}

In order to assess the baseline diversity within the Trichoderma collection of this study, a phylogeny-based analysis on the ITS region was performed. The results showed that the 67 isolates from a tropical origin clustered with the reference sequences in variable manners (Fig. 1). The clusters ranged from a pairwise configuration between an isolate and a reference sequence to groups with many isolates and more than one reference sequence. The isolates from the collection were more closely related to 11 species of the Trichoderma genus: T. asperellum, T. atroviride, T. brevicompactum, T. harzianum, T. koningiopsis, T. longibrachiatum, T. pleuroticola, T. reesei, T. spirale, T. stromaticum and T. virens. In this context, the distribution of isolates among the species was heterogeneous. The largest group comprising 27 isolates (40.3\%) was related to the T. harzianum species complex; 12 of them (17.9\%; BA107, BA121, BA166, BA139, BA140, BA154, BA148, BA132, BA167, BA141, BA157, BA155) grouped within the cluster containing the two $T$. harzianum

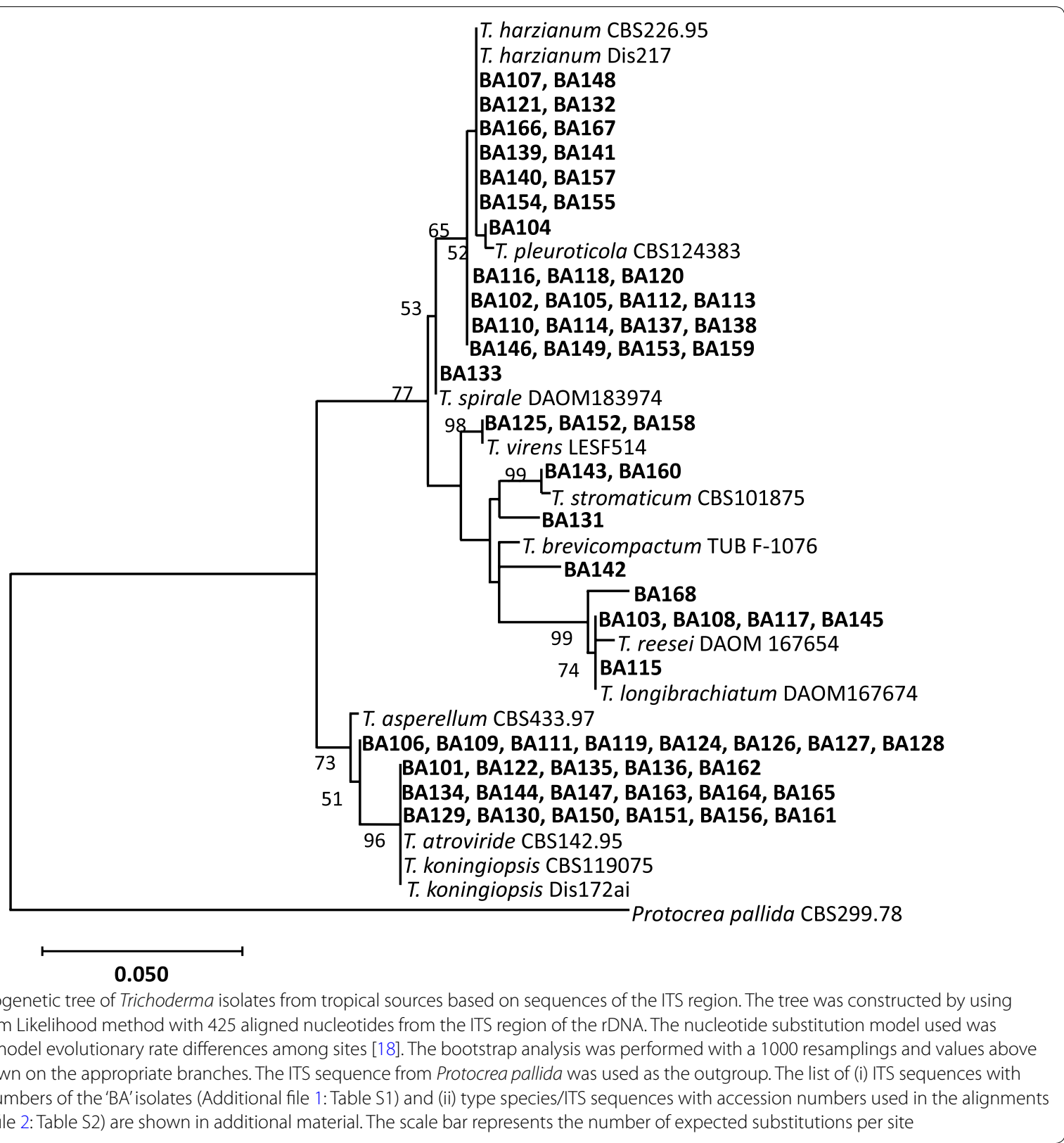


references ('CBS226.95' and 'Dis217'), and 15 (22.4\%; BA116, BA102, BA110, BA146, BA118, BA105, BA114, BA149, BA120, BA112, BA137, BA153, BA113, BA138, BA159) were more related to this cluster (Fig. 1); due to the not so close relationship to the T. harzianum reference strains, this latter group of 15 isolates were indicated as 'Trichoderma sp-1' (Additional file 1: Table S1; also see below). In terms of a first-tier, preliminary identification of the isolates based on the ITS sequences, some noteworthy certainties were verified (Fig. 1; Additional file 1: Table S1): (i) the isolate BA104 was most closely related to the T. pleuroticola species (branching out from the T. harzianum's complex); (ii) BA133 belonged in the $T$. spirale species; (iii) BA125, BA152 and BA158, grouped with T. virens; (iv) BA143 and BA160 were most closely related to T. stromaticum; and (v) BA115 belonged in the T. longibrachiatum.

The other isolates, on their turn, showed a pattern of uncertain relationship with the reference isolates, with variable levels of proximity. For instance, a cluster with 17 isolates (25.4\%) could not be distinguished from three reference sequences, the 'CBS142.95' of T. atroviride and the 'CBS119075' and 'Dis172ai' of T. koningiopsis (Fig. 1; bottom part of the dendrogram). BA131, BA142 and BA168, and a group of eight isolates (including BA106 to BA128; Fig. 1) did not form a cluster with any reference sequence. For an intra-collection differentiation, those isolates with uncertain species assignment were given an 'sp' indication, followed by specific extension numbers to represent distinct locations in the dendrogram topolgy (Additional file 1: Table S1). The T. brevicompactum, $T$. asperellum and T. reseei reference sequences ('TUB F-1076', 'CBS433.97', 'DAOM 167654', respectively) did not specifically clustered with any isolate, although the second one appeared more closely related to BA142, and the last one to BA103, BA108, BA117 and BA145 isolates (Fig. 1).

\section{Discussion}

The development of Trichoderma-based bioproducts begins with screening procedures over a hopefully variable genetic material available from collection-assembly efforts $[6,20]$, as the identification of novel genotypic variations among isolates allows to increase the options for beneficial-effects applications [21-23]. The tropical collection of Trichoderma here studied bears some genetic diversity on an isolate-specific level, based on a phylogenetic assessment with ITS sequences (Fig. 1). Despite that ITS is the primary barcode sequence for fungi, bearing several relevant features for phylogenetic/evolutionary studies in fungi $[10,11]$, alone it is not a sufficient marker for full species discrimination in highly speciose genera, such as Trichoderma [24].
Therefore, not unexpectedly, the level of similarities among all the ITS sequences was high, with differences within a range of 0.05 to 0.10 substitutions per site. However, the clustering pattern provided by the dendrogram topology suggest that the tropical isolates of this collection may be possibly assigned to more than the 11 species indicated by the reference strains (Fig. 1). The fact that more than a third of the isolates were genetically related to $T$. harzianum may be explained by the recognized condition of this taxon as a complex of cryptic species [25], in which the analysis based on ITS sequences is not able to distinguish closely related species in this complex [26]. The 11 species of Trichoderma identified/characterized in this study, coupled with the isolate-specific phenotypic aspects related to growth and sporulation responses to biotic and abiotic factors [12], suggest that the genetic diversity associated with this germplasm (at the genotypic level) will be useful for further work aiming at developing novel bioproducts with an array of possible applications. Subsequent characterization steps based on assays at laboratory and agronomic scales are needed to evaluate which isolates and conditions stand out, such as for biocontrol of phytopathogens or plant-growth promotion for distinct plant species. Once particular strains of this collection are revealed as promising sources for beneficial-effects related bioproducts, fine-tuned species definition can be achieved by characterizing other genes [24], as an aid to the ITS sequence database here provided.

\section{Limitations}

The main limitation of this study is the fact that the information contained in the ITS region is not sufficient to separate some of the isolates at the species level within the genus Trichoderma. However, since full, unequivocal taxonomy was not the main goal of this study, we claim that ITS-based preliminary characterization of Trichoderma isolates, coupled with phenotypic differences detected through specific comparative assays (e.g. [12, 21, 23]), was sufficiently appropriate to provide information on the existing diversity in this collection at the isolate (genotypic) level.

\section{Supplementary information}

Supplementary information accompanies this paper at https://doi. org/10.1186/s13104-019-4694-1.

Additional file 1: Table S1. Internal Transcribed Spacer (ITS) sequences from the 67 tropical Trichoderma isolates from the 'BA' series and the corresponding GenBank accession numbers.

Additional file 2: Table S2. List of ITS sequences from type species used in this study. 


\section{Abbreviations}

ITS: internal transcribed spacer; PDA: potato dextrose agar; PCR: polymerase chain reaction; dNTPs: deoxynucleosides triphosphate; MSA: multiple sequence alignment; NCBI: National Center for Biotechnology Information.

\section{Acknowledgements}

The authors thank the State University of Santa Cruz (UESC) and the Postgraduation Program in Genetics and Molecular Biology (PPG-GBM/UESC) for the infrastructure provided.

\section{Authors' contributions}

YBF performed the experiments, collected all the data, and helped with the analyses. YBF, LLL, RCAF and JTdS designed the project. LLL and RCAF supervised the execution of all project's steps. VC-M performed the phylogenetic analysis; VC-M and YBF wrote the draft manuscript; JTdS and LLL corrected it and provided the final MS version prior to submission. All authors contributed to the final manuscript. All authors read and approved the final manuscript.

\section{Funding}

This study was financially supported by the following Brazilian Government funding agencies: CNPq (National Council for Scientific and Technological Development) and CAPES (Coordination for the Improvement of Higher Education Personnel). CNPq funded consumables, collection of isolates, sequencing services and post-doctoral and doctoral fellowships (Project no. 402973/2012-7). CAPES funded a master's fellowship - Finance Code 001. The infrastructure was provided by the Agroindustry-applied microbiology Laboratory (LABMA) and the Center for Genetics and Biotechnology (CBG) from State University of Santa Cruz (UESC), Ilhéus-BA, Brazil.

\section{Availability of data and materials}

The data sets and working sheets are available upon request to Dr. Valter CruzMagalhães (E-mail: valter.magalhães@ufla.br) and Dr. Leandro L. Loguercio (E-mail: leandro@uesc.br).

\section{Ethics approval and consent to participate}

Not applicable.

\section{Consent for publication}

Not applicable.

\section{Competing interests}

The authors declare that they have no competing interests.

\section{Author details}

${ }^{1}$ Center of Nuclear Energy in Agriculture (CENA), State University of São Paulo (USP), Piracicaba, São Paulo 13416-000, Brazil. ${ }^{2}$ Department of Biological Sciences (DCB), State University of Santa Cruz (UESC), Ilhéus, Bahia 45662-900, Brazil. ${ }^{3}$ Department of Phytopathology (DFP), Federal University of Lavras (UFLA), Lavras, Minas Gerais 37200-000, Brazil.

Received: 17 April 2019 Accepted: 3 October 2019 Published online: 18 October 2019

\section{References}

1. Woo SL, Ruocco M, Vinale F, Nigro M, Marra R, Lombardi N, et al. Trichoderma- based products and their widespread use in agriculture. Open Mycol J. 2014;8:71-126. https://doi.org/10.2174/187443700140801 0071.

2. Holmes KA, Schroers H-J, Thomas SE, Evans HC, Samuels GJ. Taxonomy and biocontrol potential of a new species of Trichoderma from the Amazon basin of South America. Mycol Prog. 2004;3:199-210. https:// doi.org/10.1007/s11557-006-0090-z.

3. Schuster A, Schmoll M. Biology and biotechnology of Trichoderma. Appl Microbiol Biotechnol. 2010;87:787-99. https://doi.org/10.1007/ s00253-010-2632-1.

4. Harman GE, Howell CR, Viterbo A, Chet I, Lorito M. Trichoderma species-opportunistic, avirulent plant symbionts. Nat Rev Microbiol. 2004;2:43-56. https://doi.org/10.1038/nrmicro797.
5. Druzhinina IS, Seidl-Seiboth V, Herrera-Estrella A, Horwitz BA, Kenerley CM, Monte E, et al. Trichoderma: the genomics of opportunistic success. Nat Rev Microbiol. 2011;9:749-59. https://doi.org/10.1038/nrmic ro2637.

6. Glare T, Caradus J, Gelernter W, Jackson T, Keyhani N, Köhl J, et al. Have biopesticides come of age? Trends Biotechnol. 2012;30:250-8. https:// doi.org/10.1016/J.TIBTECH.2012.01.003.

7. Steyaert JM, Weld RJ, Mendoza-Mendoza A, Stewart A. Reproduction without sex: conidiation in the filamentous fungus Trichoderma. Microbiology. 2010;156:2887-900. https://doi.org/10.1099/mic.0.041715-0.

8. Steyaert JM, Weld RJ, Stewart A. Ambient pH intrinsically influences Trichoderma conidiation and colony morphology. Fungal Biol. 2010;114:198-208. https://doi.org/10.1016/J.FUNBIO.2009.12.004.

9. Steyaert JM, Weld RJ, Loguercio LL, Stewart A. Rhythmic conidiation in the blue-light fungus Trichoderma pleuroticola. Fungal Biol. 2010;114:219-23. https://doi.org/10.1016/J.FUNBIO.2010.01.001.

10. Schoch CL, Seifert KA, Huhndorf S, Robert V, Spouge JL, Levesque CA, et al. Nuclear ribosomal internal transcribed spacer (ITS) region as a universal DNA barcode marker for Fungi. Proc Natl Acad Sci USA. 2012;109:6241-6. https://doi.org/10.1073/pnas.1117018109.

11. Lindahl BD, Nilsson RH, Tedersoo L, Abarenkov K, Carlsen T, Kjøller R, et al. Fungal community analysis by high-throughput sequencing of amplified markers—a user's guide. New Phytol. 2013;199:288-99. https //doi.org/10.1111/nph.12243.

12. Feitosa YB. Evaluation of biotic and abiotic factors on growth and sporulation of tropical genotypes of Trichoderma spp. State University of Santa Cruz (UESC), Ilhéus-BA, Brazil. 2016. [M.Sc. dissertation in Portuguese].

13. Gardes M, Bruns TD. ITS primers with enhanced specificity for basidiomycetes - application to the identification of mycorrhizae and rusts. Mol Ecol. 1993;2:113-8. https://doi.org/10.1111/j.1365-294X.1993. tb00005.x.

14. White T, Bruns T, Lee $S$. Amplification and direct sequencing of fungal ribosomal RNA genes for phylogenetics. San Diego: Academic Press; 1990.

15. Altschul SF, Gish W, Miller W, Myers EW, Lipman DJ. Basic local alignment search tool. J Mol Biol. 1990;215:403-10. https://doi.org/10.1016/ S0022-2836(05)80360-2.

16. Sela I, Ashkenazy H, Katoh K, Pupko T. GUIDANCE2: accurate detection of unreliable alignment regions accounting for the uncertainty of multiple parameters. Nucleic Acids Res. 2015;43:W7-14. https://doi. org/10.1093/nar/gkv318.

17. Katoh K, Standley DM. MAFFT multiple sequence alignment software version 7: improvements in performance and usability. Mol Biol Evol. 2013;30:772-80. https://doi.org/10.1093/molbev/mst010.

18. Kumar S, Stecher G, Tamura K. MEGA7: molecular evolutionary genetics analysis version 7.0 for bigger datasets. Mol Biol Evol. 2016;33:1870-4. https://doi.org/10.1093/molbev/msw054.

19. Rambaut. FigTree. 2012.

20. Montesinos E. Development, registration and commercialization of microbial pesticides for plant protection. Int Microbiol. 2003;6:245-52. https://doi.org/10.1007/s10123-003-0144-x.

21. Loguercio LL, de Carvalho AC, Niella GR, De Souza JT, Pomella AWV. Selection of Trichoderma stromaticum isolates for efficient biological control of witches' broom disease in cacao. Biol Control. 2009;51:130-9. https://doi.org/10.1016/J.BIOCONTROL.2009.06.005.

22. Loguercio LL, Santos LS, Niella GR, Miranda RAC, de Souza JT, Collins RT, et al. Canopy-microclimate effects on the antagonism between Trichoderma stromaticum and Moniliophthora perniciosa in shaded cacao. Plant Pathol. 2009;58:1104-15. https://doi.org/10.111 1/j.1365-3059.2009.02152.x.

23. Hoyos-Carvajal L, Bissett J. Biodiversity of Trichoderma in neotropics. In: The dynamical processes of biodiversity-case studies of evolution and spatial distribution. IntechOpen. 2011. https://www.intechopen.com/ download/pdf/24420.

24. Raja HA, Miller AN, Pearce CJ, Oberlies NH. Fungal identification using molecular tools: a primer for the natural products research community. J Nat Prod. 2017;80:756-70. https://doi.org/10.1021/acs.jnatprod.6b010 85

25. Chaverri P, Branco-Rocha F, Jaklitsch W, Gazis R, Degenkolb T, Samuels GJ. Systematics of the Trichoderma harzianum species complex and 
the re-identification of commercial biocontrol strains. Mycologia. 2015;107:558-90. https://doi.org/10.3852/14-147.

26. Robbertse B, Strope PK, Chaverri P, Gazis R, Ciufo S, Domrachev M, et al. Improving taxonomic accuracy for fungi in public sequence databases: applying 'one name one species' in well-defined genera with Trichoderma/Hypocrea as a test case. Database. 2017. https://doi. org/10.1093/database/bax072.

\section{Publisher's Note}

Springer Nature remains neutral with regard to jurisdictional claims in published maps and institutional affiliations.
Ready to submit your research? Choose BMC and benefit from:

- fast, convenient online submission

- thorough peer review by experienced researchers in your field

- rapid publication on acceptance

- support for research data, including large and complex data types

- gold Open Access which fosters wider collaboration and increased citations

- maximum visibility for your research: over 100M website views per year

At BMC, research is always in progress.

Learn more biomedcentral.com/submissions 